\title{
Analisis Pemangku Kepentingan dalam Pengembangan Kawasan Cagar Budaya sebagai Destinasi Wisata Kota Pontianak
}

\author{
Stakeholder Analysis for Developing Cultural Heritage Area as a \\ Tourism Destination in Pontianak City
}

\author{
Putu Ayu Vindytha Amanda Putri ${ }^{1}$ \\ Departemen Perencanaan Wilayah dan Kota \\ Institut Teknologi Sepuluh Nopember, Surabaya, Indonesia
}

\section{Eko Budi Santoso}

Departemen Perencanaan Wilayah dan Kota

Institut Teknologi Sepuluh Nopember, Surabaya, Indonesia

Artikel Masuk : 14 Juni 2019

Artikel Diterima : 3 Agustus 2020

Tersedia Online : 31 Desember 2020

\begin{abstract}
Abstrak: Kawasan cagar budaya di Kota Pontianak membutuhkan tindakan pelestarian dengan pengembangan dan menjadikan kawasan sebagai destinasi wisata. Untuk melakukan tindakan pengembangan diperlukan orang atau kelompok yang disebut pemangku kepentingan. Tujuan dari penelitian ini adalah mengidentifikasi pemangku kepentingan yang terlibat dan hubungan di antara mereka dalam pengelolaan serta strateginya untuk mengelola kawasan cagar budaya di Kota Pontianak. Untuk mencapai tujuan dari penelitian digunakan data yang dianalisis dengan metode analisis deskriptif kualitatif dan analisis pemangku kepentingan. Setelah didapatkan hasil analisis, kemudian akan dimasukkan dalam pemodelan pentahelix untuk menjelaskan peran dan fungsi pemangku kepentingan lebih lanjut. Dari hasil analisis didapatkan pemangku kepentingan dalam pengembangan kawasan cagar budaya sebagai destinasi wisata Kota Pontianak adalah Bappeda Kota Pontianak, Dinas Kepemudaan, Olahraga dan Pariwisata Kota Pontianak, Badan Promosi Pariwisata Kota Pontianak dan Pemerintah Kecamatan Pontianak Timur sebagai pemangku kepentingan dengan pengaruh tinggi dan kepentingan tinggi. Selanjutnya adalah tokoh-tokoh masyarakat seperti sejarawan dan wisatawan sebagai pemangku kepentingan dengan pengaruh rendah dan kepentingan tinggi serta agen perjalanan wisata dan pelaku usaha fasilitas pendukung pariwisata sebagai pemangku kepentingan dengan pengaruh rendah dan kepentingan rendah.
\end{abstract}

Kata Kunci: cagar budaya; destinasi wisata; pemangku kepentingan; pemodelan pentahelix

Abstract: Cultural heritage area in Pontianak needs to be preserved by developing and transforming it as a tourism destination. To do this development, it involves some groups of people or organization as acting stakeholders. The study aimed to identify their involvement

\footnotetext{
${ }^{1}$ Korespondensi Penulis: Departemen Perencanaan Wilayah dan Kota, Institut Teknologi Sepuluh Nopember, Surabaya, Indonesia Email: putuvindytha@gmail.com
} 
and relationship in the management of and strategies for cultural heritage area in Pontianak City. The study used data which was analyzed using qualitative descriptive and stakeholder analysis methods. Then the results were incorporated into pentahelix modeling to explain further the roles and functions of each stakeholder. The results identified those acting stakeholders were of the Local Development Planning Agency of Pontianak City, the Youth, Sports and Tourism Agency of Pontianak City, the Pontianak City Tourism Promotion Board and the East Pontianak District Government with high influence and high importance. The community leaders such as historians and tourists were the stakeholders with low influence and high interests. Lastly, travel agents and tourism supporting business actors were the stakeholders with low influence and low interests.

Keywords: cultural heritage; pentahelix; stakeholder; tourism destination

\section{Pendahuluan}

Sebuah tempat dapat dikatakan sebagai kawasan cagar budaya apabila memiliki dua atau lebih bangunan atau situs cagar budaya dengan jarak yang berdekatan. Rata-rata setiap kota di Indonesia memiliki setidaknya satu atau lebih bangunan atau situs cagar budaya, salah satunya adalah Kota Pontianak, Kalimantan Barat. Kota Pontianak memiliki banyak bangunan cagar budaya dan dua di antaranya adalah Istana Kadariah dan Masjid Jami' yang letaknya berdekatan sehingga lokasi tersebut dapat dikategorikan sebagai kawasan cagar budaya.

Cagar budaya merupakan bagian dari kehidupan manusia yang secara langsung maupun tidak langsung mengakomodasi peradaban manusia dari tempat dan beragam cara hidup yang unik secara terus-menerus yang bisa saja terdiri dari alam, budaya dan bangunan pada suatu area lingkungan tertentu (Millar, 1989). Oleh sebab itu, cagar budaya perlu dilestarikan untuk menjaga arti penting warisan budaya bangsa sebagai rekaman dasar dan pengikat nilai sekaligus sebagai bukti dari pemikiran dan aktivitas manusia di masa sebelumnya (Syaifullah \& Wibowo, 2016). Salah satu cara untuk melestarikannya adalah dengan menjadikan kawasan tersebut sebagai lokasi pariwisata agar lebih dikenal masyarakat.

Kota Pontianak memiliki Bandara Supadio yang menjadi salah satu pintu masuk wisatawan dari daerah lain maupun luar negeri untuk datang berkunjung. Adanya potensi tersebut memudahkan untuk pengembangan kawasan cagar budaya sebagai lokasi pariwisata. Berdasarkan Peraturan Pemerintah Nomor 50 Tahun 2011 mengenai Rencana Pembangunan Induk Kepariwisataan Nasional Tahun 2010-2025, salah satu aspek yang dibutuhkan dalam melaksanakan pengembangan pariwisata adalah aspek kelembagaan. Hubungan kerja sama antara pemerintah dan swasta dibutuhkan dengan membagi peran masing-masing untuk mempercepat pengembangan. Peran serta masyarakat juga dibutuhkan untuk menciptakan keselarasan, keserasian dan keseimbangan demi terpeliharanya mutu dan keberlanjutan dari sumber daya itu sendiri (Prasiasa, 2013).

Pemangku kepentingan adalah individu atau kelompok yang memiliki kepentingan dan dapat memberikan pengaruh kepada suatu objek (Hidayah et al., 2019). Setiap pemangku kepentingan memiliki kepentingan dan pengaruh yang berbeda-beda (Bryson, 2004), sehingga tanggung jawab yang dimiliki juga berbeda-beda. Peran pemangku kepentingan dikelompokkan menjadi tiga yaitu pemangku kepentingan utama (primer), pemangku kepentingan pendukung (sekunder) dan pemangku kepentingan kunci (Bryson, 2004). Pemangku kepentingan utama merupakan pemangku kepentingan yang memiliki kepentingan secara langsung dengan pengambilan keputusan yang dilakukan. Pemangku kepentingan utama harus ditempatkan sebagai kelompok penentu utama dalam proses penentuan keputusan. Pemangku kepentingan ini tidak hanya bertanggung jawab dalam 
pengambilan dan implementasi keputusan namun juga yang paling menerima manfaat dari keputusan tersebut. Pemangku kepentingan pendukung (sekunder), merupakan pemangku kepentingan yang tidak memiliki kepentingan secara langsung namun memiliki kepedulian dan keprihatinan terhadap pengambilan keputusan. Kategori pemangku kepentingan ini turut memberikan sumbangsih pemikiran dan ide yang berpengaruh terhadap sikap pengambilan keputusan. Pemangku kepentingan kunci merupakan pemangku kepentingan yang memiliki wewenang legal dalam pengambilan keputusan.

Banyak penelitian yang dilakukan untuk menentukan pemangku kepentingan dalam sebuah pengembangan kawasan. Pada penelitian Handayani \& Warsono (2017), berjudul Analisis Peran Stakeholders dalam Pengembangan Objek Wisata Pantai Karang Jahe di Kabupaten Rembang, peneliti melakukan identifikasi kepada seluruh pemangku kepentingan dan membaginya menjadi tiga kelompok dan di dalamnya terdapat peranan atau posisi dari tiap-tiap pemangku kepentingan. Penelitian lainnya oleh Widodo et al. (2018) berjudul Analisis Stakeholders dalam Pengembangan Ekowisata di Taman Nasional Betung Ketihun Kabupaten Kapuas Hulu melakukan identifikasi kepada seluruh pemangku kepentingan yang terlibat dalam pengembangan dan mengklasifikasinya menjadi empat kelompok berdasarkan kriteria kepentingan dan kriteria pengaruhnya.

Kedua penelitian tersebut semuanya menerapkan stakeholders mapping, yaitu sebuah proses kolaboratif yang dilakukan dengan penelitian, debat dan diskusi untuk menarik kesimpulan daftar utama pemangku kepentingan (Maitriwaruni, 2015). Stakeholders mapping berfungsi untuk mengidentifikasi dan menilai dampak dari pemangku kepentingan melalui penilai tingkat kepentingannya (interest) dan tingkat pengaruhnya (power) (Maitriwaruni, 2015). Dibandingkan dengan penelitian lainnya, penelitian ini menggunakan pemodelan pentahelix. Pemodelan ini dibutuhkan untuk mengelola pariwisata secara lebih optimal dengan mengolaborasikan para pemangku kepentingan (Sumarto et al., 2020). Pengaplikasian pemodelan dengan tepat dapat menjadikan hubungan kerja sama dan memberikan hasil yang maksimal bagi pengembangan destinasi pariwisata (Nainggolan et al., 2020). Penelitian ini bertujuan untuk mengidentifikasi pemangku kepentingan dalam pengelolaan serta strateginya untuk mengelola kawasan cagar budaya di Kota Pontianak sehingga mempermudah penelitian lain dalam mengambil data berdasarkan sumber-sumber tersebut.

\section{Metode Penelitian}

Penelitian ini menggunakan metode penelitian kualitatif karena penelitian berdasarkan pada kondisi yang alamiah dan instrumen dalam penelitian ini berkaitan dengan manusia (Sugiyono, 2016). Teknik pengumpulan data menggunakan wawancara kepada beberapa pemangku kepentingan dengan teknik snowball sampling dan dokumen yang menjelaskan macam-macam pemangku kepentingan dan pengaruhnya terhadap pengelolaan kawasan. Narasumber wawancara berasal dari kelompok pemerintah, swasta dan masyarakat. Data tersebut kemudian dianalisis menggunakan metode analisis deskriptif kualitatif dan analisis pemangku kepentingan. Analisis pemangku kepentingan dilakukan dengan memetakan hubungan antara pemangku kepentingan, memetakan koalisinya, mengidentifikasi kekuatan dan kepentingan tiap-tiap pemangku kepentingan, menyusun matrik prioritas serta memantau kemungkinan pergeseran koalisi. Dari hasil analisis, data akan disajikan dalam bentuk tabel dan narasi. 


\section{Hasil dan Pembahasan}

\section{Kondisi Kawasan Cagar Budaya}

Kawasan cagar budaya di Kota Pontianak terletak di Kampung Dalam, Tanjung Hilir, Pontianak Timur. Kawasan memiliki dua bangunan cagar budaya yaitu Istana Kadariah dan Masjid Jami'. Istana Kadariah merupakan tempat tinggal bagi Kerajaan Pontianak yang berdiri pada tahun 1771. Masjid Jami' terletak 200 meter dari Istana Kadariah dan merupakan bangunan pertama yang dibangun oleh Kesultanan Kadariah (Elvira et al., 2018). Untuk mencapai kawasan cagar budaya bisa melalui jalan di antara permukiman warga atau menyebrangi Sungai Kapuas. Keadaan kawasan masih membutuhkan banyak pengembangan untuk dijadikan sebagai sebuah destinasi wisata (Wibowo \& Syaifulloh, 2014).

\section{Identifikasi Pemangku Kepentingan}

Seperti penelitian-penelitian sebelumnya, pengembangan sebuah destinasi wisata membutuhkan pemangku kepentingan untuk mengelola dan mengembangkan destinasi tesebut. Begitu pula dengan kawasan cagar budaya Kota Pontianak yang dimasukkan sebagai salah satu destinasi wisata oleh Pemerintah Kota Pontianak. Selain menjadi destinasi wisata, pemerintah kota juga berusaha menjaga nilai-nilai kesejarahan yang terkandung di dalam Istana Kadariah. Tugas pengembangan dan pelestarian tersebut direncanakan dan dilaksanakan oleh Dinas Kepemudaan, Olahraga dan Pariwisata. Pemerintah kecamatan juga turut membantu dalam pengembangan terutama dalam memberikan informasi kepada masyarakat mengenai program yang akan dilaksanakan. Untuk memperkenalkan kawasan cagar budaya, pemerintah kota membentuk Badan Promosi Pariwisata Kota Pontianak (BP2KP) yang terdiri dari agen perjalanan wisata di Kota Pontianak yang turut membuat promosi-promosi kepada wisatawan yang datang melalui paket-paket perjalanan wisata.

Sebuah penelitian yang berlokasi di World Heritage Sangiran yang dilakukan oleh Sugiarti et al. (2019) menemukan bahwa pengelolaan Sangiran di bawah kewenangan sebuah badan pengelola yang merupakan perwakilan dari pemerintah pusat. Namun hal tersebut berbeda dengan kawasan cagar budaya di Kota Pontianak. Istana Kadariah sampai saat ini masih dikelola oleh keluarga Kesultanan Kadariah (Wibowo \& Syaifulloh, 2014). Dari hasil wawancara, pengurusan dan pengelolaan bangunan dilakukan oleh empat orang pengurus. Masjid Jami' juga masih menjadi tanggung jawab keluarga Kesultanan Kadariah dan juga masyarakat sekitar yang masih menggunakan masjid untuk kegiatan keagamaan. Masyarakat di sekitar kawasan cagar budaya dapat memperoleh hasil dari kegiatan usaha penjualan makanan dan souvenir untuk wisatawan yang datang ke lokasi kawasan cagar budaya namun sampai sekarang pekerjaan utama masyarakat masih sebagai nelayan. Wisatawan yang datang ke kawasan saat ini hanya dimintai sumbangan secara sukarela untuk membantu sumber pendapatan Istana Kadariah. Pengetahuan tentang sejarah yang lebih dalam didapatkan dari sejarawan yang memiliki banyak dokumentasi perkembangan sejarah Kota Pontianak termasuk asal-muasal perkembangan kawasan. Untuk mendukung pengembangan kawasan cagar budaya juga terdapat beberapa penelitian oleh akademisi yang memberikan konsep-konsep pembenahan dan upaya pelestarian dan pengembangan.

Dari penjabaran pemangku kepentingan dalam pengembangan kawasan cagar budaya, pemangku kepentingan tersebut kemudian dikelompokan menjadi tiga kategori sesuai peran dan tugasnya yaitu pemangku kepentingan primer, pemangku kepentingan sekunder dan pemangku kepentingan kunci (Handayani \& Warsono, 2017). Tabel 1 berisikan pengelompokan pemangku kepentingan sesuai dengan ketiga kategori yang ada dan kepentingannya. 
Tabel 1. Pembagian Kategori Pemangku Kepentingan Pengembangan Kawasan Cagar Budaya Kota Pontianak

\begin{tabular}{|c|c|c|c|}
\hline No & Kategori & Pemangku kepentingan & Tupoksi \\
\hline \multirow[t]{4}{*}{1} & \multirow{4}{*}{$\begin{array}{l}\text { Pemangku } \\
\text { Kepentingan } \\
\text { Utama } \\
\text { (Primer) }\end{array}$} & Masyarakat & $\begin{array}{l}\text { Melakukan aktivitas dan interaksi secara langsung } \\
\text { dengan wisatawan yang berkunjung di kawasan }\end{array}$ \\
\hline & & $\begin{array}{l}\text { Pengelola / Anggota } \\
\text { Keluarga Kesultanan }\end{array}$ & $\begin{array}{l}\text { Mengelola dan menjaga Istana Kadariah dan } \\
\text { lingkungan di sekitarnya }\end{array}$ \\
\hline & & Wisatawan & $\begin{array}{l}\text { Sebagai pengunjung yang mendatangi kawasan untuk } \\
\text { tujuan wisata atau rekreasi. Jumlah kunjungan } \\
\text { menjadi tolok ukur keberhasilan pengembangan }\end{array}$ \\
\hline & & $\begin{array}{l}\text { Pelaku Usaha Fasilitas } \\
\text { Pendukung Pariwisata }\end{array}$ & $\begin{array}{l}\text { Sebagai pelaku usaha industri pariwisata dalam } \\
\text { rangka menghasilkan barang dan/atau jasa bagi } \\
\text { pemenuhan kebutuhan wisatawan }\end{array}$ \\
\hline \multirow[t]{3}{*}{2} & \multirow[t]{3}{*}{$\begin{array}{l}\text { Pemangku } \\
\text { Kepentingan } \\
\text { Sekunder }\end{array}$} & Agen Perjalanan Wisata & $\begin{array}{l}\text { Sebagai pelaku usaha industri pariwisata dalam } \\
\text { rangka memberikan jasa bagi pemenuhan kebutuhan } \\
\text { wisatawan }\end{array}$ \\
\hline & & Akademisi & $\begin{array}{l}\text { Mengetahui secara teoretis terkait dengan kawasan } \\
\text { cagar budaya, pariwisata dan bagaimana } \\
\text { pengembangan konsepnya }\end{array}$ \\
\hline & & $\begin{array}{l}\text { Tokoh Masyarakat / } \\
\text { Sejarawan }\end{array}$ & $\begin{array}{l}\text { Pihak yang mengetahui dan menyimpan informasi } \\
\text { mengenai sejarah Kota Pontianak atau yang lebih } \\
\text { luas }\end{array}$ \\
\hline \multirow[t]{10}{*}{3} & \multirow{10}{*}{$\begin{array}{l}\text { Pemangku } \\
\text { kepentingan } \\
\text { Kunci }\end{array}$} & Badan Perencanaan dan & a. Penentuan kebijakan/legalisasi objek studi \\
\hline & & $\begin{array}{l}\text { Pembangunan Daerah } \\
\text { Kota Pontianak }\end{array}$ & $\begin{array}{l}\text { b. Sebagai koordinator kegiatan perencanaan, } \\
\text { pembangunan terkait bidang fisik dan ekonomi }\end{array}$ \\
\hline & & & $\begin{array}{l}\text { c. Mengoptimalkan pemanfaatan ruang kota dengan } \\
\text { merumuskan rencana tata ruang }\end{array}$ \\
\hline & & $\begin{array}{l}\text { Dinas Kepemudaan, } \\
\text { Olahraga dan Pariwisata } \\
\text { Kota Pontianak }\end{array}$ & $\begin{array}{l}\text { a. Bidang pariwisata - pihak yang merumuskan } \\
\text { kebijakan teknis, program kerja di bidang } \\
\text { pariwisata. }\end{array}$ \\
\hline & & & $\begin{array}{l}\text { b. Pembinaan dan pengendalian teknis di bidang } \\
\text { pariwisata }\end{array}$ \\
\hline & & Badan Promosi & Memperkenalkan dan mempromosikan pariwisata \\
\hline & & Pariwisata Kota & Kota Pontianak ke dalam dan luar daerah \\
\hline & & Pontianak (BP2KP) & \\
\hline & & $\begin{array}{l}\text { Pemerintah Kecamatan } \\
\text { Pontianak Timur }\end{array}$ & $\begin{array}{l}\text { a. Mewadahi kepentingan dan aspirasi masyarakat } \\
\text { di tingkat Kecamatan Pontianak Timur }\end{array}$ \\
\hline & & & $\begin{array}{l}\text { b. Melaksanakan tugas administrasi di tingkat } \\
\text { regional kecamatan }\end{array}$ \\
\hline
\end{tabular}

\section{Stakeholders Mapping}

Setelah ditentukan dalam pengkategorian pemangku kepentingan, maka yang dapat dilakukan selanjutnya adalah stakeholders mapping. Pemetaan dilakukan untuk melihat kedudukan tiap-tiap pemangku kepentingan berdasarkan kepentingannya dan pengaruhnya terhadap pengelolaan dan pengembangan kawasan cagar budaya di Kota Pontianak.

\section{Tingkat Kepentingan (Interest)}

Pemangku kepentingan dalam pengelolaan dan pengembangan kawasan cagar budaya di Kota Pontianak memiliki kepentingan yang berbeda-beda. Kepentingan dinilai dari seberapa besar individu atau kelompok tersebut memiliki kepentingan dalam mengelola dan menerima hasil pengelolaan. Tingkat kepentingan pemangku kepentingan dibagi menjadi dua yaitu pemangku kepentingan dengan kepentingan tinggi mengelola 
seluruh program dan pemangku kepentingan rendah. Yang pertama adalah kelompok pemangku kepentingan berkepentingan tinggi yang biasanya terdapat pada kategori pemangku kepentingan kunci.

Pemangku kepentingan yang memiliki kepentingan tertinggi adalah Dinas Kepemudaan, Olahraga dan Pariwisata Kota Pontianak terutama pada Bidang Destinasi Wisata dan Bappeda Kota Pontianak. Rencana Strategis (RENSTRA) Pemerintah Kota Pontianak 2015-2019 yang mengamanatkan "Terwujudnya Kota Pontianak sebagai Daerah Tujuan Wisata yang Berbudaya, Terdepan di Kalimantan Barat" mengarahkan kawasan cagar budaya yang dimiliki oleh Kota Pontianak sebagai suatu potensi yang dapat dikembangkan menjadi sebuah produk pariwisata. Bappeda sebagai perancang program pemerintah berperan mengoptimalkan pemanfaatan tata ruang pada kawasan sehingga pengembangan pada kawasan lebih terarah dan lebih mudah mencapai tujuan pengembangan. Selain itu, Bappeda juga sebagai koordinator kegiatan perencanaan dan pembangunan sehingga kepentingan Bappeda dalam pengembangan ini cukup besar. Selanjutnya terdapat Badan Promosi Pariwisata Kota Pontianak (BP2KP) menjadi badan pemerintah yang mengatur promosi yang harus dilakukan sehingga pengembangan kawasan cagar budaya sebagai destinasi wisata lebih terarah dan tepat sasaran. Tidak hanya dari pemerintah kota, pemerintah kecamatan, terutama Kecamatan Pontianak Timur, juga memiliki kepentingan dalam mewadahi aspirasi masyarakat untuk kemudian disampaikan kepada pemerintah kota sebagai bahan pertimbangan pengembangan dan menyosialisasikan program pemerintah kepada masyarakat dalam kawasan. Dengan kepentingan keempat pemangku kepentingan ini, maka kegiatan pengembangan terlaksana dan mendapatkan hasil yang sesuai dengan tujuan.

Pemangku kepentingan yang juga memiliki kepentingan tinggi dalam pengembangan adalah individu atau kelompok yang ada di dalam kawasan cagar budaya yaitu pemilik sekaligus pengelola dari bangunan cagar budaya, masyarakat yang tinggal di sekitar kawasan cagar budaya, sejarawan dan juga wisatawan yang datang. Kelompok ini adalah kelompok yang menjadi kelompok yang harus dipertimbangkan dalam membuat program dan sebagai penerima hasil dari pengembangan. Pemilik Istana Kadariah yang masih merupakan Keluarga Kesultanan Kadariah bertugas menjaga dan mengelola Istana Kadariah dan sekitarnya, sehingga perlu ada pertimbangan dan persetujuan dari pihak ini apabila kawasan akan dilakukan pengembangan. Selain itu, sejarawan juga memiliki kepentingan yang tinggi karena memberikan infromasi sejarah yang menjadi nilai-nilai yang perlu dipertahankan dalam pengembangan. Masyarakat yang menjadi penerima hasil dari pengembangan perlu dipertimbangkan kepentingannya dan masyarakat juga memiliki kepentingan dalam melanjutkan program pengembangan sehingga terdapat keberlanjutan program ini. Terakhir adalah wisatawan sebagai salah satu tujuan pengembangan. Jumlah kunjungan wisata menjadi salah satu tolok ukur untuk mengetahui keberhasilan dari pengembangan.

Kategori selanjutnya adalah pemangku kepentingan dengan kepentingan rendah yang terdiri dari pelaku usaha fasilitas pendukung pariwisata, agen perjalanan wisata, dan akademisi. Pelaku usaha pendukung pariwisata mungkin tidak hanya terdapat dalam kawasan tetapi juga seluruh pelaku usaha pendukung di Kota Pontianak menjadi salah satu pendukung kegiatan pariwisata yang akan dikembangkan. Begitu pula dengan agen perjalanan wisata yang akan mendukung promosi pariwisata dan menyiapkan paket-paket perjalanan wisata termasuk pada kawasan ini. Adapun akademisi berkontribusi secara tidak langsung melalui penelitian-penelitian di bidang pengembangan wisata, pengelolaan tempat wisata ataupun pengembangan dan pelestarian cagar budaya. Penelitian dari akademisi ini menjadi pertimbangan alternatif pengembangan yang akan dikembangkan. 


\section{Tingkat Pengaruh (Power)}

Pemangku kepentingan pada pengelolaan dan pengembangan kawasan cagar budaya di Kota Pontianak memiliki pengaruh yang berbeda-beda pula. Pengaruh dinilai dari seberapa besar pemangku kepentingan memberikan pengaruh terhadap pengelolaan dan pengembangan dan mendapatkan pengaruh dari pengelolaan dan pengembangan. Pengaruh dikelompokkan menjadi dua yaitu pemangku kepentingan dengan pengaruh tinggi dan pengaruh rendah.

Kelompok pemangku kepentingan dengan pengaruh tinggi yang pertama adalah Dinas Kepemudaan, Olahraga dan Pariwisata Kota Pontianak yang bertugas menyusun program-program pengembangan pariwisata. Dinas ini bekerja sama dengan Bappeda dan Pemerintah Kecamatan Pontianak Timur dalam menentukan kebijakan pengelolaan dan pengembangan kawasan cagar budaya yang terletak di Kecamatan Pontianak Timur. Selain itu, BP2KP juga memiliki pengaruh tinggi untuk menarik wisatawan dengan programprogram promosi yang direncanakan. Pemangku kepentingan lain yang juga memiliki pengaruh yang cukup besar adalah pemilik sekaligus pengelola kawasan cagar budaya. Pemangku kepentingan ini berpengaruh karena tanpa persetujuan dari mereka maka program-program tersebut tidak diperbolehkan untuk diaplikasikan. Masyarakat sekitar juga berpengaruh dalam mempertimbangkan program-program apa saja yang tidak hanya menguntungkan kawasan tetapi juga masyarakat di sekitarnya. Selain itu, masukan dari masyarakat sebagai penghuni dan keikutsertaannya sangat berpengaruh untuk keberlanjutan program.

Pemangku kepentingan yang masuk dalam tingkat pengaruh rendah adalah wisatawan, pelaku usaha fasilitas pendukung pariwisata, agen perjalanan wisata, sejarawan dan akademisi. Wisatawan tidak memiliki pengaruh terhadap penentuan program oleh pemerintah. Begitu pula dengan pelaku usaha fasilitas pendukung pariwisata dan agen perjalanan wisata merupakan pemangku kepentingan yang memiliki tujuan mengambil keuntungan dari pengembangan, sehingga kelompok ini hanya mengikuti programprogram yang sudah disediakan oleh pemerintah. Peran sejarawan kurang berpengaruh terhadap program, karena hanya sebagai pemberi masukan terhadap pengelolaan kawasan cagar budaya. Dan terakhir akademisi memiliki pengaruh rendah karena dari hasil penelitiannya, bahkan terkadang pelaksanaan pengelolaan, masih merasakan kurangnya informasi yang dapat dilaksanakan di lapangan.

Setelah dilakukan pembagian setiap kepentingan dan pengaruh, seluruh pemangku kepentingan kemudian pemangku kepentingan akan ditempatkan pada empat penentuan yang berbeda-beda seperti pada Gambar 1. Pembagian tersebut antara lain, (1) pengaruh tinggi - kepentingan tinggi, termasuk dalam kelompok pemangku kepentingan kunci yaitu Bappeda Kota Pontianak, Dinas Kepemudaan, Olahraga dan Pariwisata Kota Pontianak, Badan Promosi Pariwisata Kota Pontianak dan Pemerintah Kecamatan Pontianak Timur. Selain itu, masyarakat dan pengelola maupun anggota keluarga Kesultanan Kadariah juga memiliki pengaruh dan kepentingan yang tinggi, karena tanpa persetujuaan dan keikutsertaannya, maka program ini tidak dapat berjalan, (2) pengaruh rendah kepentingan tinggi, adalah tokoh-tokoh masyarakat seperti sejarawan dan wisatawan, dan (3) pengaruh rendah - kepentingan rendah, adalah agen perjalanan wisata dan pelaku usaha fasilitas pendukung pariwisata dalam ataupun sekitar kawasan.

\section{Peran dan Fungsi Pemangku Kepentingan}

Peran dan fungsi masing-masing pemangku kepentingan berbeda-beda sesuai kepentingan dan pengaruhnya. Peraturan Menteri Pariwisata Republik Indonesia Nomor 14 Tahun 2016 menjelaskan bahwa untuk menciptakan dan memastikan kualitas dari aktivitas, fasilitas, pelayanan dan pengalaman serta memberikan manfaat dan keuntungan dari 
pariwisata kepada masyarakat dan lingkungan, maka perlu adanya optimasi peran dari komunitas, pemerintah, akademisi, pebisnis dan media. Optimasi tersebut dituangkan dalam bentuk pemodelan pentahelix. Pemangku kepentingan dalam pemodelan ini terdiri dari lima elemen yaitu akademisi, pemerintah, komunitas, bisnis dan media massa yang memiliki peran masing-masing (Yuningsih et al., 2019). Unsur-unsur dari pentahelix ini diharapkan mampu memperkuat sinergi sehingga mendorong program pemerintah pusat dengan pengelolaan destinasi wisata (Junaid, 2019). Pembagian peran pemangku kepentingan dalam pemodelan pentahelix diilustrasikan pada Gambar 2.

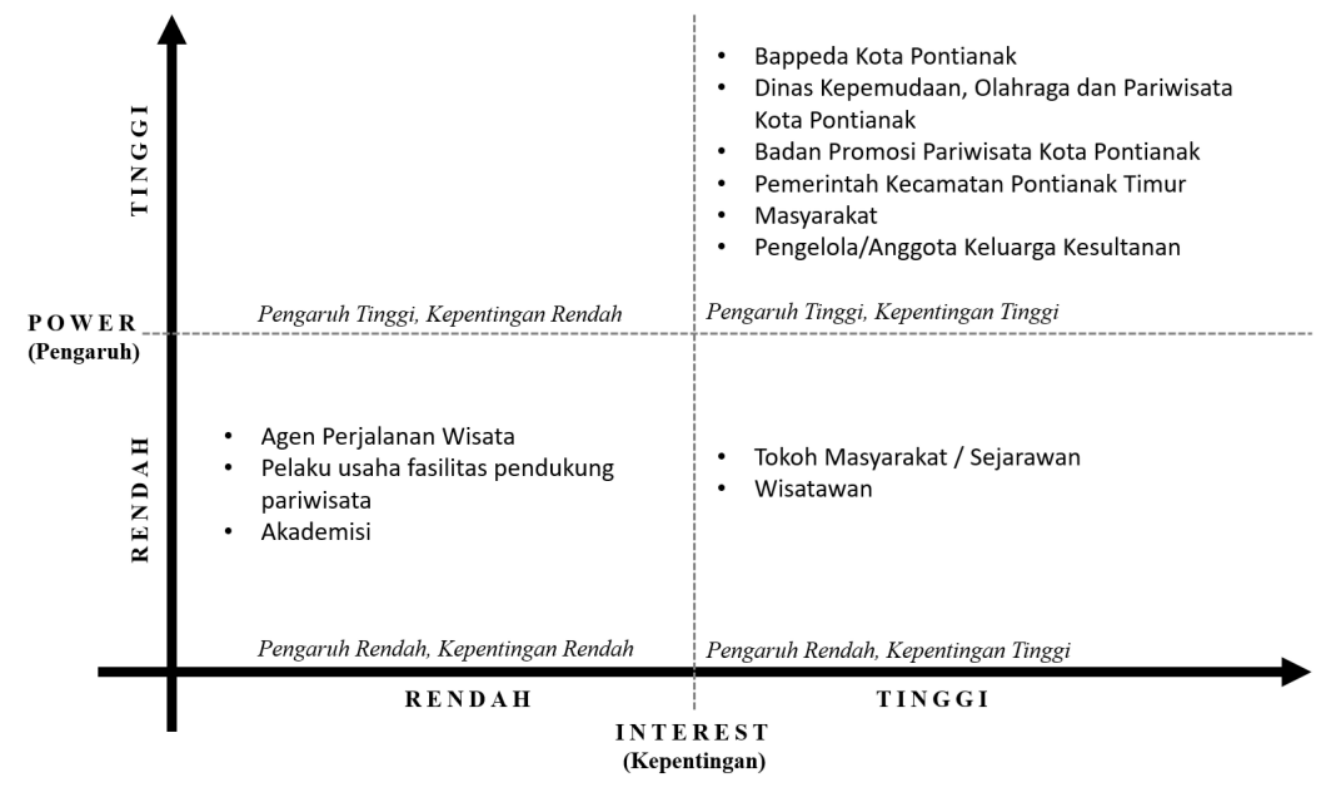

\section{Gambar 1. Tingkat Pengaruh dan Kepentingan Pemangku Kepentingan}

Peran pemangku kepentingan pengembangan kawasan cagar budaya di Kota Pontianak saling bersinergi satu sama lain. Pertama adalah akademisi yang berperan sebagai konseptor. Akademisi memberikan sumbangsih ilmu pengetahuan melalui konsep, teori terbarukan dan relevan sesuai dengan kondisi kawasan. Konsep dan teori tersebut dapat dijadikan masukan dalam perencanaan kawasan maupun pengawasan kinerja pelaksanaan kegiatan yang telah dilakukan oleh seluruh pihak. Kota Pontianak sendiri memiliki banyak universitas dan sekolah menengah kejuruan yang berkaitan dengan pariwisata, sejarah maupun perancangan kota yang akan memberikan sumbangsih ilmu untuk pengembangan kawasan cagar budaya.

Kedua adalah sektor swasta atau pebisnis yang berperan sebagai enabler. Enabler berperan untuk membantu pencapaian tujuan. Pada pengembangan kawasan ini pebisnis adalah agen-agen perjalanan wisata. Agen-agen ini bertugas mempromosikan kawasan sebagai sebuah destinasi wisata kepada para wisatawan yang akan berkunjung. Selain itu, agen perjalanan wisata juga dapat menampung aspirasi dari pihak wisatawan mengenai pengalaman-pengalaman dari kunjungan yang dilakukan. Kota Pontianak sendiri memiliki asosiasi yang menaungi agen-agen perjalanan wisata tak hanya di Kota Pontianak tetapi juga Kalimantan Barat yaitu Asosiasi Tour and Travel Agent (Asita) Kalbar.

Pemangku kepentingan ketiga adalah pemilik bangunan cagar budaya dan tokoh masyarakat di sekitar kawasan. Kelompok ini berperan sebagai akselerator antara pemangku kepentingan lain dan masyarakat. Bangunan cagar budaya dalam kawasan ini masih menjadi milik Kesultanan Kadariah. Seluruh kegiatan berkaitan dengan bangunan 
dalam kawasan masih menjadi tanggung jawab dari keluarga kesultanan. Selain itu, masyarakat yang tinggal di sekitar kawasan juga bisa menjadi akselerator kepada masyarakat luar mengenai kawasan tersebut.

Pihak keempat adalah pemerintah yang terdiri dari Dinas Olahraga, Kepemudaan dan Pariwisata dan Bappeda Kota Pontianak. Pemerintah berperan sebagai regulator sekaligus pengontrol. Pemerintah terlibat dalam seluruh kegiatan seperti perencanaan, pelaksanaan dan pengawasan. Pemerintah juga berperan sebagai koordinator dari seluruh pemangku kepentingan yang terlibat. Dinas Olahraga, Kepemudaan dan Pariwisata dalam RENSTRA 2015-2019 memiliki perencanaan apa saja yang menjadi fokus pengembangannya dan menjelaskan bagaimana pelaksanaan tiap fokus. Selain itu dalam RENSTRA 2015-2019 juga dijelaskan kinerja-kinerja yang telah dilakukan dan hasil yang telah didapatkan. BP2KP juga berperan sebagai regulator sekaligus pengontrol di bidang promosi pariwisata Kota Pontianak.

Pihak kelima adalah media yang berperan sebagai expander. Media mempromosikan, memublikasikan dan membuat citra kawasan untuk diperkenalkan kepada masyarakat luar dan wisatawan sehingga tertarik akan pengembangan destinasi ini. Media promosi bisa saja berupa iklan di media cetak, iklan di televisi nasional dan pamflet-pamflet yang diletakan di pintu-pintu kedatangan wisatawan. Selain itu, promosi media juga telah berkembang ke area digital seperti website wisata Kota Pontianak yaitu pontianakite.com yang merupakan kerja sama antara Disbudpar dan Forum Koordinasi Bujang Dare Pontianak.

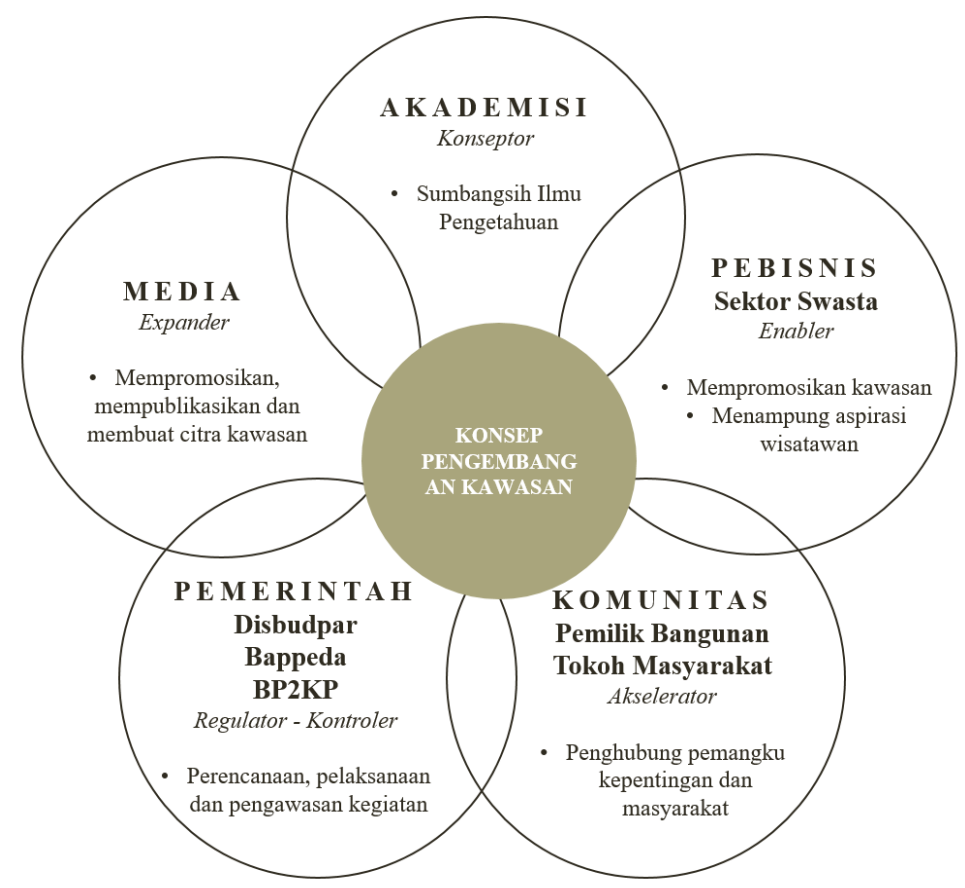

Gambar 2. Pemodelan Pentahelix Pemangku Kepentingan Pengelola Kawasan Cagar Budaya Kota Pontianak

\section{Hubungan Antar Pemangku Kepentingan}

Dari pemodelan pentahelix, didapatkan peran dan fungsi setiap pemangku kepentingan. Salah satu penelitian yang dilakukan oleh Nurulwahida et al. (2020) menjelaskan peran dan fungsi dari setiap pemangku kepentingan pada Kajoetangan Heritage di Kota Malang dengan pemodelan pentahelix. Namun tidak dijelaskan apakah 


\section{Analisis Pemangku Kepentingan dalam Pengembangan Kawasan Cagar Budaya...}

setiap pemangku kepentingan memiliki hubungan satu sama lain sedangkan dalam pemodelan ini dapat dijelaskan hubungan satu sama lain seperti pada Gambar 3.

Akademisi memiliki hubungan networking dengan bisnis dalam bertukar informasi untuk pengembangan program. Akademisi dan komunitas memiliki hubungan coordinating karena akademisi tidak terlalu banyak bersinggungan dengan komunitas namun tetap harus menjalin hubungan saling berbagi sumber daya. Akademisi memiliki hubungan collaborating dengan pemerintah. Akademisi merupakan pemangku kepentingan konseptor yang harus berkolaborasi dengan pemerintah untuk menciptakan konsep atau ide-ide pengembangan terbaru. Yang terakhir, hubungan akademisi dengan media yaitu networking. Akademisi dan media tidak memerlukan hubungan yang intensif namun saling terhubung dalam publikasi.

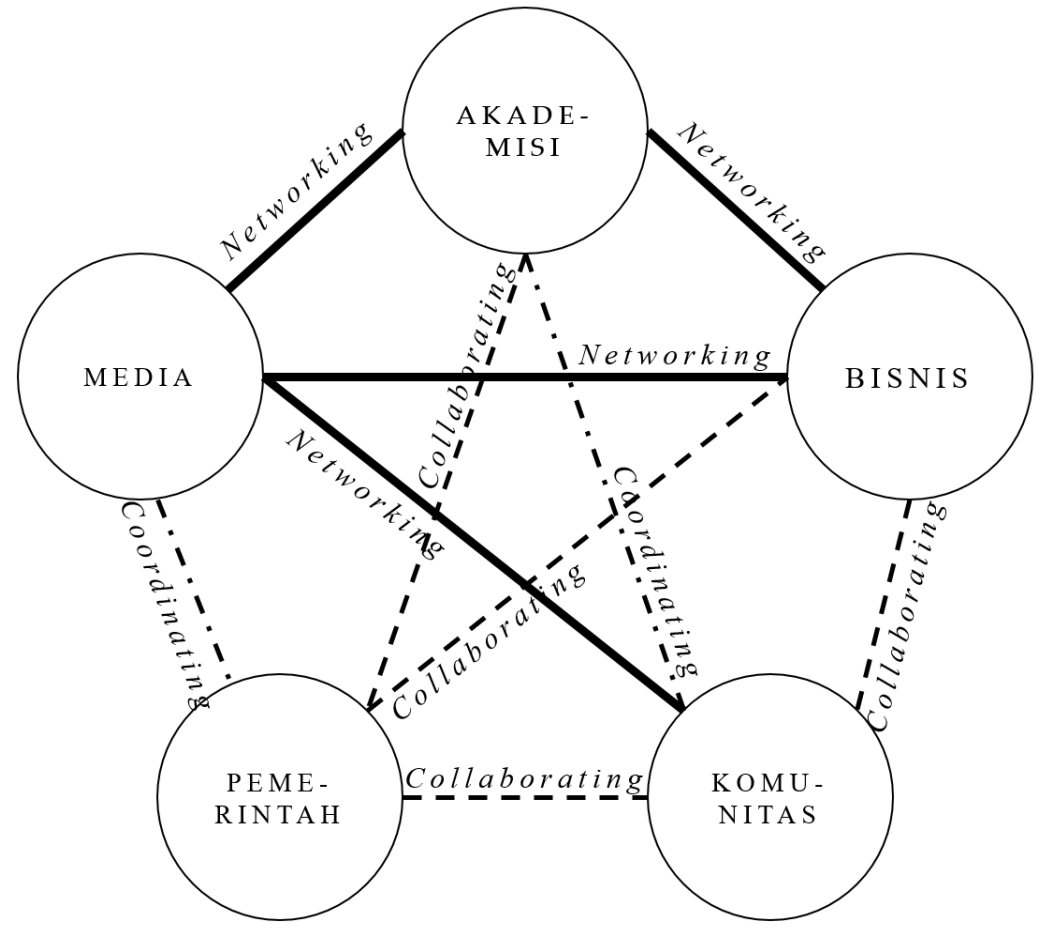

Gambar 3. Hubungan Antar Pemangku Kepentingan Pengelola Kawasan Cagar Budaya Kota Pontianak

Bisnis dan komunitas memiliki hubungan collaborating. Bisnis memberikan peluang bagi komunitas untuk proses bisnis seperti memperoleh informasi bisnis atau memberikan pelatihan bisnis kepada komunitas. Bisnis juga memiliki hubungan collaborating dengan pemerintah. Pemerintah membuka peluang-peluang munculnya bisnis baru dengan ide-ide atau putusan perencanaan bisnis yang bisa dikembangkan di sekitar kawasan cagar budaya yang akan diminati wisatawan. Dengan media, bisnis memiliki hubungan networking dengan cara media memberikan dukungan publikasi pengembangan bisnis yang ada di dalam kawasan cagar budaya.

Komunitas dan pemerintah memiliki hubungan collaborating dari berbagi tanggung jawab dan risiko pelaksanaan kegiatan pengembangan. Pemerintah melakukan perencanaan dengan mempertimbangkan komunitas di dalam kawasan cagar budaya sedangkan komunitas di dalam kawasan cagar budaya melaporkan hal-hal yang dibutuhkan untuk melakukan pengembangan pada kawasan cagar budaya. Hubungan komunitas dan media adalah networking. Komunitas dan media tidak memerlukan hubungan resmi dalam hal bertukar informasi namun media membutuhkan informasi dari komunitas untuk bahan 
publikasi bagi kepentingan pemerintah dan komunitas memerlukan informasi untuk mengetahui perkembangan lebih lanjut mengenai pelaksanaan kegiatan. Sementara itu, hubungan pemerintah dan media adalah coordinating manakala media memublikasikan kinerja pemerintah untuk informasi kepada masyarakat, dan berfungsi untuk kegiatan pengawasan sementara pemerintah mendapatkan informasi perkembangan yang terjadi, sehingga pemerintah dapat meningkatkan, memperbaiki dan berinovasi untuk pelaksanaan selanjutnya.

Keterlibatan pemangku kepentingan dalam pengembangan kawasan cagar budaya di Kota Pontianak terkadang menghadapi kendala dalam koordinasi. Perlu adanya hubungan yang kuat di antara pemangku kepentingan sehingga program dapat berjalan dengan optimal. Pemerintah sebagai koordinator harus mampu mengoordinasi pemangku kepentingan lain untuk menjalankan tugasnya sesuai dengan tupoksinya. Pemangku kepentingan lain juga harus aktif dalam berkontribusi untuk pengembangan kawasan cagar budaya yang berhasil.

\section{Kesimpulan}

Setiap pemangku kepentingan memiliki pengaruh dan kepentingannya sendiri. Kelompok kategori pemangku kepentingan kunci berperan sebagai regulator dan pengontrol sehingga dapat dijadikan sebagai ketua perencanaan, pelaksanaan dan pengawasan kegiatan. Pengelola/anggota keluarga Kesultanan Kadariah dan tokoh masyarakat/sejarawan berperan sebagai akselerator, pelaku usaha fasilitas pendukung pariwisata dan agen perjalanan wisata berperan sebagai enabler mempromosikan kawasan, akademisi berperan konseptor dengan menyumbangkan konsep dan ide pengembangan melalui penelitian. Yang terakhir adalah media yang berperan sebagai expander dengan mempromosikan, memublikasikan dan membuat citra kawasan pada masyarakat luar.

Peran-peran tidak hanya teridentifikasikan namun membentuk hubungan kerja sama dalam pemodelan pentahelix antar pemangku kepentingan yang sesuai berdasarkan pemangku kepentingan dari kawasan cagar budaya di Kota Pontianak. Dengan adanya hubungan kerja sama seperti coordinating, networking, collaboration yang baik di antara pemangku kepentingan maka menghindari terjadinya konflik kepentingan, dan lebih mudah menentukan siapa yang harus terlibat dalam kaitannya dengan pengembangan yang ada, serta siapa yang membutuhkan peningkatan sehingga pengembangan menjadi lebih mudah. Pada akhirnya, penelitian ini berkontribusi membantu penelitian mengenai pengembangan wilayah khususnya kawasan cagar budaya di Kota Pontianak dalam menentukan siapa saja yang dibutuhkan dalam pengembangan. Selain itu, penelitian ini juga membantu penelitian lain dengan konsep ataupun kawasan cagar budaya lainnya dalam menentukan para pemangku kepentingan yang dibutuhkan.

\section{Daftar Pustaka}

Bryson, J. M. (2004). What to do when stakeholders matter: stakeholder identification and analysis techniques. Public Management Review, 6(1), 21-53. doi:10.1080/14719030410001675722.

Elvira, Zain, Z., Mulyani, R. E., \& Rudiyono. (2018). Identifikasi bangunan masjid Jami’ Keraton Pontianak sebagai upaya konservasi bangunan cagar budaya. In Seminar Nasional Penerapan Ilmu Pengetahuan dan Teknologi 2018 (pp. 137-149). Pontianak: Universitas Tanjungpura.

Handayani, F., \& Warsono, H. (2017). Analisis peran stakeholders dalam pengembangan objek wisata Pantai Karang Jahe di Kabupaten Rembang. Journal of Public Policy and Management Review, 6(3), 40-53. doi:10.14710/jppmr.v6i3.16543.

Hidayah, N., Hutagalung, S. S., \& Hermawan, D. (2019). Analisis peran stakeholder dalam pengembangan wisata talang air peninggalan kolonial Belanda di Kelurahan Pajaresuk Kabupaten Pringsewu. Jurnal Ilmu 


\section{Analisis Pemangku Kepentingan dalam Pengembangan Kawasan Cagar Budaya...}

Administrasi Publik, 71), 55-71. doi:10.31289/publika.v7i1.2179.

Junaid, I. (2019). Model sinergi unsur pentaheliks pariwisata dalam pengelolaan destinasi wisata Kota Parepare dan Kabupaten Bone. Sosiohumaniora: Jurnal Ilmu-IImu Sosial dan Humaniora, 21(1), 22-33. doi:10.24198/sosiohumaniora.v21i1.17016.

Maitriwaruni, M. D. A. (2015). Analisis penerapan stakeholder mapping dan pengaruhnya pada keberlanjutan bisnis perusahaan: Studi kasus pada perusahaan farmasi - PT Sandoz Indonesia. Universitas Indonesia.

Millar, S. (1989). Heritage management for heritage tourism. Tourism Management, 10(1), 9-14. doi:10.1016/0261-5177(89)90030-7.

Nainggolan, M., Ardika, I. W., Ardhana, I. K., \& Setiawan, I. K. (2020). Pentahelix model application for tourism development strategy. International Journal of Linguistics, Literature and Culture, 6(2), 12-18. doi:10.21744/ijllc.v6n2.864.

Nurulwahida, S., Syafrieyana, Y., \& Sukmana, O. (2020). Collaboration with pentahelix model in developing Kajoetangan Heritage tourism in Malang city. Journal of Local Government Issues, 3(1), 1-17. doi:10.22219/logos.v3i1.10699.

Prasiasa, D. P. (2013). Destinasi pariwisata berbasis masyarakat. Jakarta: Salemba Humanika.

Sugiarti, R., Warto, W., \& Sutirto, T. W. (2019). Partisipasi pemangku kepentingan dalam mendukung revitalisasi aset wisata pusaka di Kawasan World Heritage Sangiran. Cakra Wisata Jurnal Pariwisata dan Budaya, 20(2), 17-34.

Sugiyono. (2016). Metode penelitian kuantitatif, kualitatif dan $r \& d$. Bandung: PT. Alfabeta.

Sumarto, R. H., Sumartono, S., Muluk, M. R., \& Nuh, M. (2020). Penta-Helix and Quintuple-Helix in the management of tourism villages in Yogyakarta City. Australasian Accounting, Business and Finance Journal, 14(1), 46-57. doi:10.14453/aabfj.v14i1.5.

Syaifullah, M., \& Wibowo, B. (2016). Pemanfaatan benda cagar budaya sebagai potensi pariwisata dan ekonomi kreatif bagi masyarakat sekitar di Kota Pontianak Kalimantan Barat. Sejarah dan Budaya: Jurnal Sejarah, Budaya, dan Pengajarannya, 19(2), 222-233.

Wibowo, B., \& Syaifulloh, M. (2014). Optimalisasi Kraton Kadariyah dalam pengembangan pariwisata di Kota Pontianak Kalimantan Barat. Jurnal Edukasi, 1(1), 11-27. doi:10.31571/edukasi.v12i1.187.

Widodo, M. L., Soekmadi, R., \& Arifin, H. S. (2018). Analisis stakeholders dalam pengembangan ekowisata di taman nasional Betung Kerihun Kabupaten Kapuas Hulu. Jurnal Pengelolaan Sumberdaya Alam dan Lingkungan, 8(1), 55-61. doi:10.29244/jpsl.8.1.55-61.

Yuningsih, T., Darmi, T., \& Sulandari, S. (2019). Model pentahelik dalam pengembangan pariwisata di Kota Semarang. JPSI (Journal of Public Sector Innovations), 3(2), 84-93. doi:10.26740/jpsi.v3n2.p84-93. 